\title{
Rotational grazing of dairy cows : effect of grazing intervals on animal and grass production
}

\author{
F Chenais 1, R Espinasse 2, M Leroux 2 \\ Institut de l'Élevage, Monvoisin, BP 67, 35650 Le Rheu; '2EDE des Côtes d'Armor, BP 540 , \\ 22195 Plérin Cedex, France
}

With rotational grazing, short grazing intervals allow to feed grass of good value : this method enhances animal performance but reduces grass production. Inversely, according to Frame and Hunt, (1971, J Br Grassld Soc, 2, 163-171) and Binnie and Chestnutt (1991, Grass and Forage Sci, 46, 343-350), longer intervals improve grass production but reduce grass value and quality. Furthermore, two advantages could be obtained with longer intervals :

- a larger amount of grass available for grazing in summer, which could lower the acreage of grass to be cut for silage in spring ;

- a longer period of grazing without supplement of forage, but with possibly a lower milk production.

During 3 years (1992 to 1994), perennial ryegrass swards have been rotationally grazed, form early may to mid-september (paddocks of 1 hectare each). Two groups of Holstein cows ( 4 th to 8 th month of lactation) have been used, with 17,26 or 21 cows in each group, respectively for trial 1,2 and 3 :

- group S (short) with grazing intervals of 18 to 25 days in spring and 25 to 35 days in summer ; cows were moved from a paddock to another in order to obtain an optimum milk production ;

- group L (long) with longer intervals, of 23 to 33 days (spring) and 33 to 50 days (summer), and cows moving from a paddock at a very low sward height.
During the periods of deficiency for grass production, cows were fed a supplement of maize silage (group $S$ ) or grass silage (group L). Sward heights were checked (40 measurements per paddock) with a grassmeter, when animals entered or leaved each paddock.

On average, during 3 years, intervals for group $L$ were longer : 6.6 days (spring) and 11.5 (summer) more than for group $\mathrm{S}$. Longer intervals were associated with higher sward heights, when cows entered into a paddock : +2 to $+4 \mathrm{~cm}$, at the various stages of grazing season. At the end of each paddock, sward heights were similar for the two groups. A low stubble height was reached with many difficulties in group L, and the same height was reached very easily in group $\mathrm{S}$. Treatment $\mathrm{L}$. was associated with a smaller grazing area per cow, especially in spring. For the two groups, milk production and milk fat percentage were similar ; but milk protein percentage was slightly lower for group $\mathrm{L}$, particularly in summer.

To sum up, longer intervals between successive grazings have very little effect on milk production. This method allows to have a larger stock of grass available, associated with a lower acreage to be cut for silage ; a longer grazing period is also possible, without supplement of forage. But longer intervals must be associated with a very short grazing, before moving cows from a paddock.

\begin{tabular}{lccccccc}
\hline Periods & \multicolumn{2}{c}{ Spring } & \multicolumn{2}{c}{ Summer } & \multicolumn{2}{c}{ Whole period } \\
Treatments & \multicolumn{3}{c}{$\mathrm{S}$} & $\mathrm{L}$ & $\mathrm{S}$ & $\mathrm{L}$ & \multicolumn{2}{c}{$\mathrm{S}$} & $\mathrm{L}$ \\
\hline Grazing intervals (d) & 21.8 & 28.4 & 28.4 & 39.9 & & 25.6 & 35.0 \\
Sward heights & & & & & & \\
$\quad$ available herbage (cm) & 13.1 & 16.8 & 11.9 & 14.0 & 12.6 & 15.3 \\
$\quad$ stubble (cm) & 6.9 & 6.6 & 6.9 & 7.1 & 6.9 & 6.9 \\
Silage in summer (kg of DM/cow) & 0 & 0 & 370 & 150 & 370 & 150 \\
Milk production (kg) & 25.7 & 25.6 & 20.2 & 20.0 & 22.6 & 22.3 \\
Fat (\%) & 3.81 & 3.83 & 3.79 & 3.79 & 3.81 & 3.81 \\
Protein (\%) & 3.00 & 2.96 & 3.19 & 3.07 & 3.10 & 3.02 \\
\hline
\end{tabular}

